\title{
A Rare Cause of Acute Abdomen: Mesenteric Cyst Torsion
}

\section{Nadir Bir Akut Batın Nedeni: Mezenter Kist Torsiyonu}

\author{
Feyzi Kurt ${ }^{1}$, İlhan Korkmaz ${ }^{2}$
}

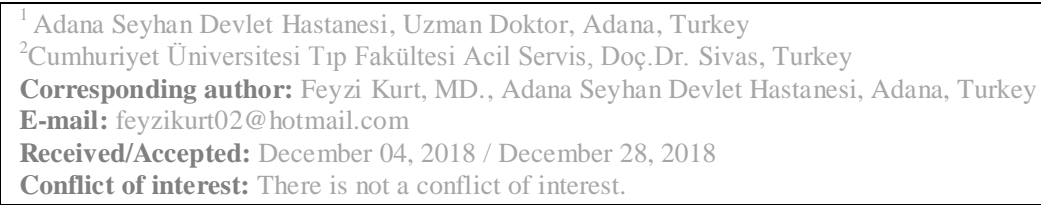

\section{SUMMARY}

Mesenteric cysts are seen rarely and most of them are seen in the childhood period. The lack of characteristic clinical features and radiological signs may present great diagnostic difficulties. The cyst may present with diffuse abdominal swelling, abdominal pain or abdominal mass. Malignant cysts occur in less than $2 \%$ cases. Surgery is the treatment of choice.

Keywords: Mesenteric cyst, abdominal pain, abdominal swelling, acute abdomen.

\section{ÖZET}

Mezenter kistleri daha çok çocukluk yaş grubunda nadir görülen kistlerdir. Kendilerine özgü klinik ve radyolojik bulguları yoktur. Bu nedenle tanıları zordur. Genellikle karında şişkinlik, ağrı ve karında asimetrik, simetrik büyümeye ile görülürler. Kistlerin ancak \%2 sinde malignite tespit edilir. Tedavisi cerrahidir ve kistin eksizyonunu kapsar. Anahtar sözcükler: Mezenter kisti, karın ağrısı, karında distansiyon, akut abdomen.

\section{INTRODUCTION}

Mesenteric cysts are formed by the obstruction of the misplaced lymphatics and are rare in adults. ${ }^{1,2}$ Ectopic localization of the lymphatic system, infection or trauma are among the reasons suggested in the etiology. Histologically the presence of fibrous wall without epithelium suggests a traumatic cyst. Endothelial and epithelial layer are defined in different type of mesenteric cysts. Mesenteric cysts are defined as serous, chylous, or hemorrhagic according to their contents. Sizes usually range between 5-30 $\mathrm{cm} .{ }^{1,2,3}$. Most frequently $(80 \%)$ they originate from ileum and jejenum. ${ }^{4}$, Malignant degenerations of these tumors are rare. The diagnosis is made occasionally, clinically after the enlargement of the mesenteric cysts that can be palpated in physical examination or radiologically which is performed for other reasons. Nevertheless, they can cause life-threatening acute abdomen as a result of the complications that occur (ileus, volvulus, cyst's rupture or infection). ${ }^{5-8}$

İnspite the fact that mesenteric cysts are seen generally, we would to emphasize that mesenteric cysts may a reason for acute abdomen in elderly patients

\section{CASE}

A 74-year-old female patient was admitted to our emergency department with complaints of nausea, vomiting, abdominal pain and abdominal distention. The patient was experiencing abdominal distention for about 6 months. There was no feature in her background. Biochemical and hematological parameters were normal. On physical examination, there was asymmetry on the right side of the abdomen giving a mass image up to the pelvis. The bowel sounds were reduced. There was widespread defenses and rebounds in her physical examination. Liver and spleen could 
not be palpated. There was intense gas in the intestines without any air-fluid levels. Ultrasonography and computed tomography showed a cystic lesion of $108 \times 55 \mathrm{~mm}$ size with thick septations in the pelvic region. (Figure 1) In the inferior laterally neighborhood of this lesion, a second lesion with multiloculated expansions was observed. There was a $17 \times 16 \mathrm{~mm}$ solid mass attached to the cystic lesion wall. There was no free fluid in the patient's abdomen tomography.
The patient was taken into operation after necessary preparations. There was necrosis and chylous fluid in the abdomen extending from the umbilicus to the pelvis. the mass was released by sharp and blunt dissection. The cyst originating from the ileum cyst had been torsion around the pedicle. Total cystectomy was performed. The patient did not develop any complication in the postoperative period and was discharged on the 2nd day.

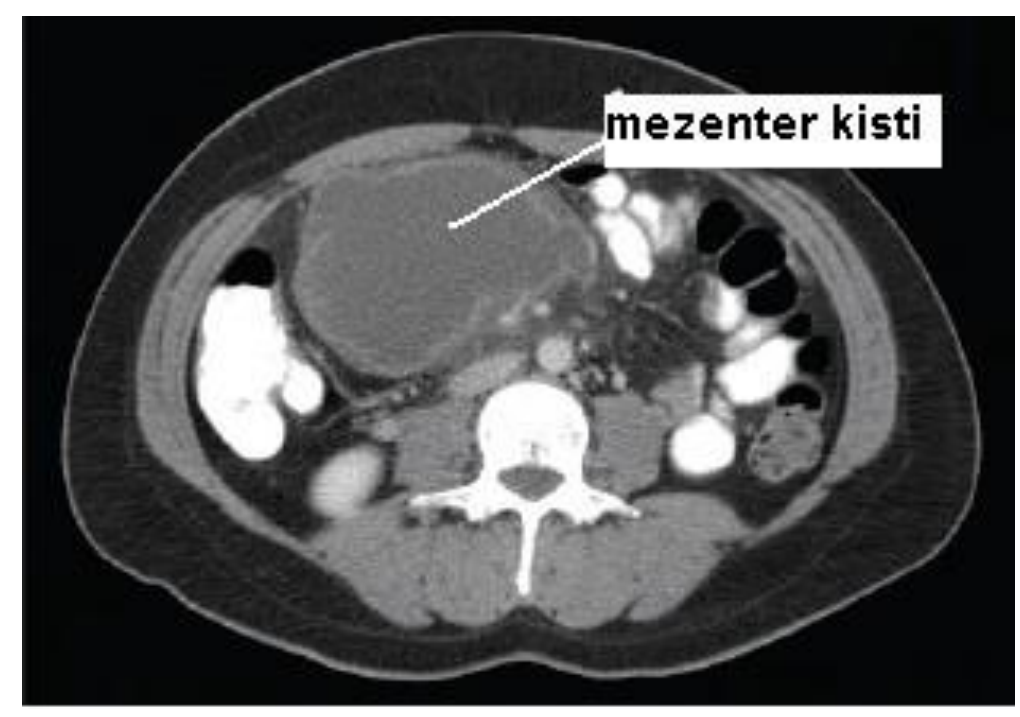

\section{DISCUSSION}

Antonio Benivieni is a surgeon from Florence who defined mesenteric cysts in $1507 .{ }^{9}$ İnspite of many suggestions about the pathogenetic mechanism of the mesenteric cysts origin, the definition made by Grosfeld is the mostly accepted. Grosfeld defined it as benign ectopic lymphatics in the mesentry without any communication to the other lymphatic system. ${ }^{10}$ Mesenteric cysts are usually benign. The structures are unilocular, multilocular, and internal structures are fibrously walled with single row endothelium. They contain serous or chylous fluids and can reach large sizes with their multilocular structures. ${ }^{11}$ Most of the mesenteric cysts develop from ileum. A smaller proportion develops from the other parts of the colon and the jejunum, respectively. While the content of cysts that develop from the small intestine mesosis is chylous, the content of those originating from the colon is more serous. 


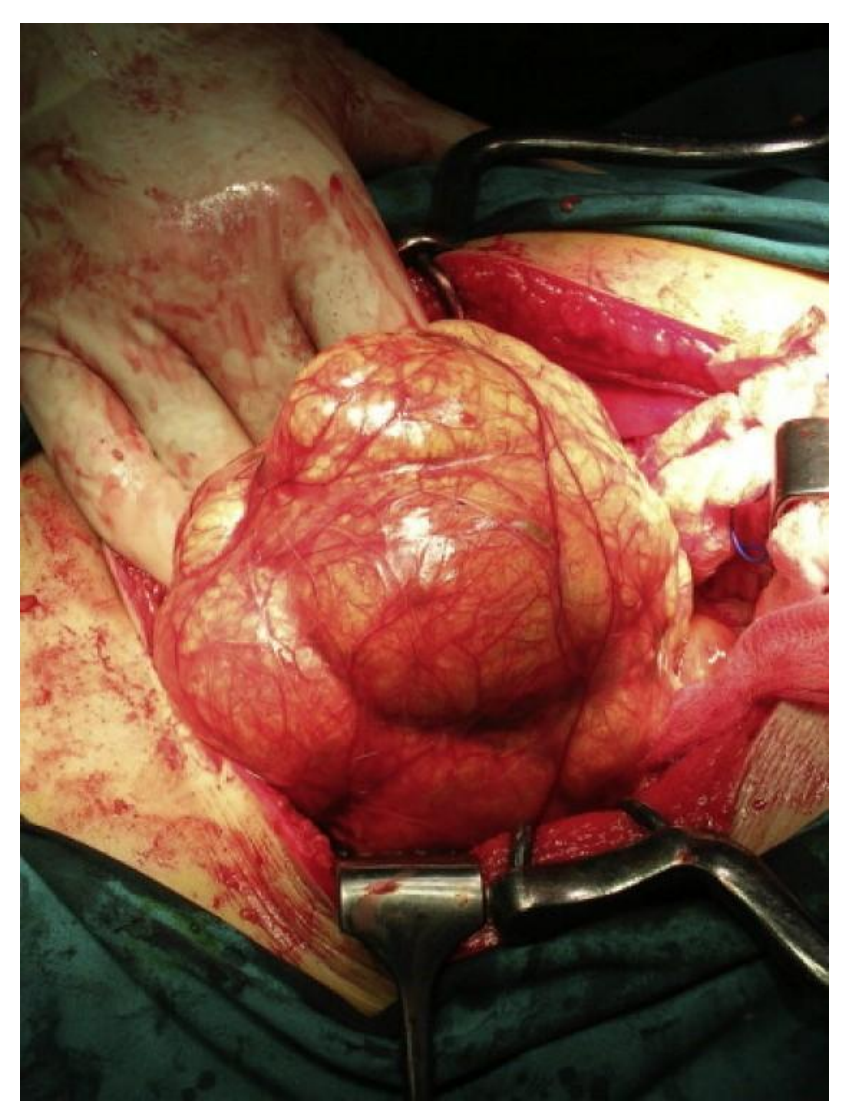

Mesenteric cysts may be mixed with enteric duplication or pancreatic pseudocysts. Mesenteric cysts may be asymptomatic or cause abdominal distention, nausea, vomiting and abdominal pain if they are enlarged. Intestinal obstruction, volvulus, bleeding into the cyst and torsion are the complications that can refer to acute abdominal pain. Symptoms are not disease specific and varies according to the location of the cyst. They are detected as a mobile mass that does not show soft sensitivity. The most common complication is the obstruction of the small intestine that is compressed by mesenteric cyst. Volvulus or torsion of the cyst is a less common complication. Bleeding as a result of trauma causes sudden growth and pain. Traumatic rupture of the cyst, torsion, urinary obstructions and malignant changes are rare complications. Very rarely, the cyst is perforated and can be the reason of generalized peritonitis. The definitive treatment of mesenteric cysts involves surgical total excision. But in some cases, it may not be possible to completely remove the cyst. A segment of the small intestine may need to be removed. In our case, we were able to remove the cyst completely and there were no complications. In this study, we presented the case to remind that acute abdomen may develop in the elderly patients due to complications of mesenteric cysts.

\section{REFERENCES}

1.Vanet VW, Philips AK. Retroperitoneal,mesenteric and Omental cysts.Arch surg 1984,199:838-42.

2.Chou Yh, Tiu CM, Lui WY, Chang T.Mesenteric and omental cysts:An ultrasonographic and clinical study of 15 patients. Gastrointest Radiol 1991, 16:311-4.

3.Liew SCC,Gleen DC, Storey DW. Mesenteric cyst. Aust NZ J Surg 1994, 64:741-4.

4.Ros PR, Olmsted WW, Moser RP,et al. Mesenteric and omental cysts. Histological classification with imaging correlation. Radiology 1987,164:327-32.

5. A. Casarotto, A. Cerofolini, F. Denitto, et al., Mesenteric cyst: case report and review of the literature, G. Chir. 31 (2010) 239e242.

6. B.N. Wani, S.N. Jajoo, K.B. Golhar, A.M. Bhole, Mesenteric cyst causing acute intestinal obstruction: a rare occurrence, Trop. Gastroenterol. 32 (2011) 246e248.

7. P.R. Ros, W.W. Olmsted, R.P. Moser Jr., A.H. Dachman, B.H. Hjermstad, L.H. Sobin, Mesenteric and omental cysts: histologic classification with imaging correlation, Radiology 164 (1987) 327e332. 
8. C. Rispoli, N. Rocco, L. Iannone, B. Amato, Developing guidelines in geriatric surgery: role of the grade system, BMC Geriatr. 9 (Suppl. 1) (2009) A99

9. Kurtz Robert J [1] , Heimann Tomas M, Robert BA, James H. Mesenteric and retroperitoneal cysts. Ann Surg. 1986;203:109-12

10. Richard R.R. Mesenteric and omental cysts. In: Grosfeld J.L., O'Neill J.A. Jr., Coran A.G., Fonkalsrud E.W., editors. Pediatric Surgery. 6th ed. Mosby Elsevier; Philadelphia: 2006. pp. 1399-1406.

11.Chung MA,Brant ML,St-Vil D,Yazbeck S.Mesenteric cysts in children. J Pediatr Surg 1991:26:1306-8. 